\title{
RSU1 Gene
}

National Cancer Institute

\section{Source}

National Cancer Institute. RSU1 Gene. NCI Thesaurus. Code C24757.

This gene plays a role in signal transduction and is involved in cell adhesion. 